Faculty of Medicine

University of Belgrade

Serbia

\author{
Danka Sinadinović ${ }^{* *}$ \\ Faculty of Medicine \\ University of Belgrade \\ Serbia
}

\title{
A BLENDED ELECTIVE MEDICAL ENGLISH COURSE: PRACTICAL IMPLICATIONS
}

\begin{abstract}
The elective course English Language 4 at the Faculty of Medicine, University of Belgrade is a blended course combining online with hands-on classroom teaching and learning. It includes writing an analytical essay on the rules of composing and delivering a conference presentation; individual designing and delivering of an actual presentation on a given, medicine-related topic; writing an analytical essay on the rules of designing and presenting a conference poster; making and presenting an actual conference poster on a given medicine-related research paper in pairs. The entire course is carried out as a series of intermittent online activities and classroom sessions. This format has been designed and tailored over time to meet the specific needs of medical students. The paper highlights the practical implications of the course and its actual benefits for the students.
\end{abstract}

Key words: blended learning, English in medicine

\section{Introduction}

English language courses are offered at the Faculty of Medicine, University of Belgrade, both as compulsory courses: English Language 1 and 2, and as elective courses: English Language 3, 4 and 5. English Language 1 (first year of medical studies) and 2 (second year of medical studies) are part of the compulsory curriculum, lasting two semesters i.e. 30 weeks, each. Their primary focus is on grammar, medical English vocabulary, reading (comprehension), writing and listening skills. These

\footnotetext{
*Faculty of Medicine, University of Belgrade, Dr Subotića 8, 11000 Belgrade, Serbia; e-mail: seasparkling@ yahoo.com

${ }^{* *}$ Faculty of Medicine, University of Belgrade, Dr Subotića 8, 11000 Belgrade, Serbia; e-mail: dankas78@ gmail.com
} 
courses are classroom-based, and, due to space and time constraints, they are taught in large groups (70-120 students) once a week for a period of 1.5 hours. The level of English competency in the groups is far from uniform, ranging from intermediate to proficiency. The same is true of motivation levels.

Elective courses: English 3, 4 and 5, lasting one semester, i.e. 15 weeks each, are offered in years 3,4 and 5, respectively. The focus of English Language 3 is on writing and speaking skills (CV, motivation letter, case report, mock doctor-patient interview, etc.); English Language 4 focuses on conference skills - writing and speaking (conference presentations and posters); while English Language 5 primarily deals with academic writing skills (abstract and research paper). The elective course student groups are significantly smaller (10-30 students) than those for compulsory English courses (E1 and E2), while the level of English competency is more balanced and usually quite high, i.e. most students who select these courses have high scores on their English 1 and 2 tests, and they are usually quite fluent and motivated.

Since their introduction at the Faculty of Medicine of Belgrade University (almost 15 years ago) English elective courses have developed and evolved. From the onset, the goal of the courses was enabling students to reach higher level skill sets, beyond just grammar, vocabulary, reading and comprehension. The aim was to help students master skills that would help effectively function in the world of medical reading, writing, presentation and communication (clinical, conference and research settings).

Initially, elective courses were all classroom based but have gradually transformed into blended courses combining classroom and online instruction and learning. The rationale behind this transition was a combination of student needs (as assessed by the teachers and resulting from direct feedback from students over the years), student time constraints (medical students have increasingly busier and busier schedules) and the desire to motivate students to participate in these courses by adjusting the design of the courses to ever-changing and developing technology, which, indeed, constantly offers new possibilities.

Blended learning provides flexibility in tailoring courses to the needs of student groups, but also to each individual student, at the same time enabling the teacher to maintain the structure of the course and fulfill its goal.

This is why this type of course has, at one point, become recognized as an excellent choice for elective English courses at the Faculty of Medicine, University of Belgrade, with Elective English 4 being the first course with such a format at the Department of Humanities (other departments had already started with individual blended courses). 
The aim of this paper is to present the development of the content, design and format of English Language 4 at the Faculty of Medicine and describe its transition from a classroom-based to a blended course.

\section{Blended learning}

The term blended learning (also known as hybrid learning) refers to courses that combine classical face-to-face classes with so-called distance learning. Distance learning involves the use of technology, which enables students to have access to learning materials any time they want (Lungu 2013: 471). Osguthorpe and Graham (2003) see the blended learning approach as "a harmonious balance between online access to knowledge and face-to-face human interaction". As the number of universities using blended learning is constantly growing, it is believed that most of the courses will be hybrid in the near future (Young 2002: 33-34).

Owing to the distance learning component, the concept of blended learning is closely connected to computer assisted language learning (CALL), which is believed to help learners achieve learning autonomy, become aware of their learning goals and consequently achieve better results (Barson 1999). Veselá (2012: 59) describes CALL as task-based and interractive, and she believes it largely contributes to learnercentredness, connectivism and collaboraton. CALLincludes web governing, multimedia support, animation, as well as the development of blended teaching systems (Jović and Stevanović 2015: 372). It relies on infromation and communication technologies which provide resources and motivation for teachers and students (Chapelle 2001: 175). In online and blended courses, teachers have various tools at their disposal, including mail, conferencing, online learning systems (Daud and Zubairi 2006: 7), as well as Google groups and personal websites (Mijomanović et al. 2018: 43).

Some important differences have been noticed between a computer-assisted classroom and a traditional (oral) classroom. First of all, the teacher's role is minimized in the computer-assisted classroom (Sullivan and Pratt 1996: 491). Consequently, in online and hybrid systems, teachers are seen as challengers, motivators or navigators (Veselá 2012: 50-51) and they do not have a dominant role typical of the traditional classroom. However, using technology and combining online and traditional classes does not mean teachers will become redundant - on the contrary. Fotos and Brown (2004: 7) claim technology cannot possibly replace teachers, but that teachers have to use technology if they do not want to become obsolete. Sotillo (2000: 83) believes online instruction is superior to face-to-face instruction, but only with the help of experienced and skillful teachers who know what they are doing. 
Several studies report various positive effects of a computer-assisted classroom. According to Sullivan and Pratt's study (1996: 496), 100\% of students participated in the computer-assisted class in comparison with only $50 \%$ of students who did so in the traditional class. Similar results were presented by Kelm (1992) and Kern (1995), who reported $86-92 \%$ participation in online courses and only $37-60 \%$ participation in class discussions (oral classrooms). Thirunarayanan and Perez-Prado (2001) proved that online students achieved better results than students in the traditional classroom, whereas Yu-Chih and Cifuentes (2001) came to the conclusion that students' participation in online learning had resulted in improving their active learning skills and becoming better at critical inquiry and reflective thinking. Mijomanović et al. (2018: 45-46) report students' valuable opinions on the computer-assisted classroom and online courses. Students' impressions were mostly positive: they praised the handson aspect of the tasks, learning new communication skills and achieving new insights into writing skills and certain aspects of their future profession. They described the structure of the course as time-saving, they appreciated the possibility of collaborating with their peers and flexibility in doing the assignments, and they also praised the effort and creativity put into the course as well as well-designed tasks (Mijomanović et al. 2018: 47-48). According to Lungu (2013: 470), introducing blended-learning technology in ESP classes means: a) faster and better learners, flexible learning environment, greater autonomy and self-pacing in task completion, and b) more time for teachers to explore resources and organize interesting classes. Lungu (2013: 473) also reports that students appreciate the opportunity to communicate with their teacher any time, via e-mail, the fact they spend less time in the classroom, and good student rapport.

On the negative side, some students had problems with the mailing system via Google groups (their emails were not always compatible with this platform), some of them complained of lacking live interaction with the teacher, and some had problems with the (demanding) level of English they were exposed to (Mijomanović et al. 2018: 48). In some other studies it was noticed that some learners felt uncomfortable with the electronic environment as it was not spontaneous enough (Beaudoin 2002), that there could be problems with slow-responding peers (Yu-Chih and Cifuentes 2001), and that some students felt isolated and missed the interaction of the traditional classroom (Dziombak 1990).

\section{English Language 4-Blended elective course at the Faculty of Medicine, University of Belgrade}

\subsection{Course curriculum}

The English Language 4 course curriculum covers the following medical topics: 
- Talking to patients

- Chronic non-infectious diseases (atherosclerosis, coronary disease)

- Infectious diseases

- Immunization (vaccination and treatment)

- Viral diseases I (viral hepatitis, etc.)

- Viral diseases II (pneumonia, etc.)

- Internal Medicine I (diabetes mellitus, obesity, metabolic disorders etc.)

- Internal Medicine II: Skin diseases

- History Taking in Neurology

- Neurological disorders (cerebro-vascular insult and others)

- Multiple Sclerosis and Parkinson's disease

- Psychiatric Interview

- Psychoses (depression, mania, schizophrenia)

- Addictions

- Principles of rehabilitation (physiotherapy)

\subsection{Phase 1 of course development}

In the first phase (course taught by professor Sofija Mićić Kandijaš, $\mathrm{PhD}$ ) the curriculum envisaged covering the topics listed under 3.1, mainly through:

- reading and analyzing research papers and abstracts from scientific journals

- researching medical literature and the Internet for information on set topics

- composing presentations related to the given topics

- writing summaries

- reading and reporting medical news

- writing case reports, summaries, essays (Mićić 2009: 484).

The course was classroom based and ended with a written examination.

\subsection{Phase 2 of course development}

In the second phase (course taught by lecturer Biljana Vukčević Lacković) a significant shift in skill focus and course format was made transforming it from a classroom-based course to a blended course.

A blended course, combining classroom with online learning and teaching, was introduced for the first time at the Department of Humanities of the Faculty of Medicine. The remaining two elective English courses were later transformed in a similar way. 
The course made another significant shift, incorporating the concept of interdisciplinary teaching and learning as well as peer review.

While the topics defined by the curriculum remained the same, the course format was completely redesigned in order to facilitate the development of conference skills: conference presentation writing and delivery, and conference poster presentation writing and delivery. In other words, the topics were now used as the basis for student assignments, i.e. tasks, while the assignments themselves became a tool for developing specific conference skills necessary in the real world of science and research presentation.

The aim of the tasks was to prepare students to competently compose and present a conference presentation and a conference poster. To this end they completed a series of assignments, i.e. tasks. Throughout the process they received feedback from the teacher but also from their peers through peer evaluation. The tasks were carried out as a combination of group and individual work and were completed partially inside of class and partially outside of class and sent to the teacher electronically.

At the beginning of this phase of course development, the course still concluded with a written examination, consisting of an essay related either to conference presentation writing or conference poster structure. This exam was, however, subsequently eliminated, i.e. the completion of set assignments automatically made the students eligible to pass.

\subsubsection{Phase 2 of course development - course outline}

Introductory class with students (Class 1)

- Description of the course in detail, including tasks, deadlines for the completion of each task, methods of communication, forming a joint mailing group, etc.

- Discussing the course with the students, clarifications, providing students with a chance to express their expectations

- Discussing Task 1

- Allocating topics from the list of topics, as defined by the course curriculum, for Task 3: one topic per student (students chose the topics themselves, but each had to choose a different one.)

\section{Task 1}

Task 1 was an individual effort completed outside of class and submitted to the teacher electronically.

Students received, via e-mail, a number of articles, presentations and papers on the rules (including dos and don'ts) of conference presentation writing and conference presentation delivery (oral presentation). This included information on various issues 
related to content (rule of three, relevance, information hierarchy, etc.), format (font, colors, amount of text, etc.), tools (graphs, charts, etc.), oral delivery (posture, eye contact, voice volume, etc.) and other relevant issues.

The task was to study the material and extract two concise yet comprehensive bullet point lists that depict the major rules of writing (List 1), and orally delivering a conference presentation (List 2). The number of rules per list could not exceed 12 .

When completed (within a set deadline), the lists were sent to the teacher via e-mail, for approval. In order to be approved, the lists needed to be sufficiently comprehensive, yet concise. Where necessary, feedback was given, and the students amended the lists accordingly.

Once all the lists were approved, another class (Class 2) was scheduled for completing Task 2. (The deadlines and classes were planned, as much as possible, to accommodate the students' needs and outlined at the beginning of the course, i.e. in Class 1.)

\section{Task 2}

Task 2 was a group effort carried out in class. The whole group pooled their individual lists together to compare, contrast and discuss the items on these lists. The students were required to reach a consensus on the most important rules of composing and delivering a conference presentation by creating two joint and uniform lists of rules that would be used by everyone in the group as a mini rulebook for performing Task 3 . These final lists could also not exceed 12 rules per list, so a complete consensus had to be reached within the group since every member had to abide by these rules accordingly.

At the beginning of the class, the teacher explained the aim of the class and instructed the students to select a group leader to steer and moderate the discussion.

After initial instructions, the teacher did not moderate this class, but merely stood by to answer any questions that might arise.

Once finished, the lists were sent by the appointed group leader to all participants and the teacher, via e-mail.

\section{Task 3}

Task 3 was an individual effort completed outside of class and submitted online to the teacher. Feedback for the task was also provided online, individually. Presentation delivery was an individual task performed in class, in front of the whole group.

Within an agreed upon deadline, students researched their chosen topic and put together a Power Point presentation covering the topic (maximum length: ten minutes). For this they used research papers and other appropriate literature they found themselves. In composing the presentation, the students had to abide by the rules of 
writing a conference presentation they had themselves agreed upon when creating the final joint lists.

They sent their presentations to the teacher, via e-mail, for approval. In the meantime, while researching and writing the presentation, they could, at any given moment, contact the teacher, again via e-mail, with any questions they might have. The communication with the teacher was, therefore, active and constant.

Once sent, the teacher inspected the presentations, provided individual feedback on necessary corrections and adjustments, with explanations and clarifications. The students sent their corrected versions to the teacher, and once the final versions were complete, the teacher approved them.

Once the presentations were all approved, the group met (Class 3) and each student delivered their presentation. While presenting, the students were required to abide by the rules of oral presentation that they had themselves agreed upon when creating the final joint lists.

After their presentation, each student was given feedback by the teacher, but also by their colleagues (peer review). Everyone was required to provide feedback for everyone. The guidelines for feedback were the lists.

Through the process of completing the first three tasks, as described above, the students were guided towards completing and presenting a comprehensive, yet concise, well organized and relevant presentation, such as they would be expected to prepare and present at any medical conference, symposium or other similar event. They received continuous feedback from the teacher during the process and were thus able to correct, alter and perfect their lists and presentations, learning as they went along. Additionally, they were able to discuss and better understand the process through initial group discussion and consensus on the most important rules, i.e. attributes of a good presentation. This made adopting and applying the rules easier. Since the students themselves agreed on the lists of rules, they were more prone to accepting them and abiding by them. Direct comments and feedback on the quality of the presentations and oral presenting skills, received from the teacher and the entire group after each presentation, often inspired a discussion which most of the students found very helpful and valuable as it often flushed out many issues and challenges that students had experienced during the process of presentation design, but also the issues they face when presenting orally. These were discussed and ways for overcoming them were also explored.

\section{Task 4}

Task 4 was a group effort, completed outside of class through small group meetings and submitted to the teacher online. Feedback by the teacher to the groups 
was also provided online. Group poster presentations were carried out in class, where the groups also received feedback from other groups and the teacher.

Namely, at the end of Class 3, small groups (2-3 students) were formed, a topic was chosen by each group (from the remaining topics on the list defined by the curriculum) and the principles of conference poster writing and presentation were briefly discussed. A deadline for poster presentation was agreed upon.

The teacher sent the students reference literature related to conference posters. This included information on various issues pertaining to the aims of a conference poster, its structure, content, design, format and presentation.

The students were required to study the literature, and then agree, within their small groups, upon the most important rules of conference writing and presentation. They then researched the topic they had chosen and, as a group, created a poster covering that topic. The poster needed to cover the topic generally, in brief, but also to primarily present a piece of research related to that topic (research paper, or similar, found online or provided by the teacher).

The students needed to abide by the rules of poster writing and presentation they had themselves agreed upon when analyzing the literature in their small groups. This part of the process was not controlled by the teacher; rather, the students were encouraged to monitor the process and assign group roles themselves.

Once completed, the posters (in electronic form) were sent to the teacher and were approved after feedback had been provided and corrections had been made. Just like for the previous one, for this task, open communication with the teacher, via e-mail, was also maintained throughout.

The group met (Class 4) to present their posters, whose final versions they had printed out. An actual conference setting was imitated in the process: posters were put up on walls, students inspected each other's posters, posed questions and provided feedback to each other. The teacher actively took part, not as a moderator, but rather as a participant, posing questions and commenting with all the other members of the groups.

\section{Task 5}

Task 5 was related to writing abstracts for research papers and conferences. However, it was subsequently (in Phase 3 of course development) transferred from this course to the English Language 5 course (which was simultaneously restructured), therefore it will not be described in this paper.

At the end of the course the students were invited to give their opinions and input regarding the course, its quality and relevance. This input was then used to further develop and fine tune the course. The input was not collected through any 
structured evaluation sheet, but rather in conversations with the students as well as through e-mails written by students. Namely, upon the successful completion of all tasks, students were invited to express their opinion on the course with concrete and detailed comments on what they found useful and what they would change in all the phases of the process.

Most of the students expressed appreciation for the process of creating both the presentation individually, and the poster as a group, and found that it had been beneficial, as by the end of it they had mastered useful and applicable skills, and at the same time learned new and creative ways of successfully working with one another. Many openly stated that they were happy to step out of the somewhat artificial world of classroom learning and to learn and practise presentation skills instead, which they recognized as useful and necessary.

\subsection{Phase 3 of course development}

In this, current, phase, the course, taught by assistant professor Danka Sinadinović, $\mathrm{PhD}$, has undergone a significant shift regarding its format, transforming it from a blended to a predominantly online course. This shift was, primarily, the result of an effort to meet student needs and their class and examination dynamics at the School of Medicine.

Upon taking over the course, the teacher recognized that, while the course was devoted to valuable skills, appreciated by students, they had begun to express the need for a greater flexibility in course design and delivery, so as to make more time for their challenging schedules of classes, colloquiums and examinations pertaining to clinical courses, which they felt to be immensely more important than their elective English course. In other words, they wanted to be able to complete the tasks within the defined deadlines, with more freedom to do so at their own pace, and without too many classes set in the classroom.

Recognizing these needs, the teacher attempted to meet them by restructuring the organization of the course, at the same time retaining, as much as possible, its effectiveness in developing skills related to conference presentation and poster design and delivery. The number of classes was, therefore, cut. At the same time online communication between the teacher and the students was intensified, in order to effectively compensate for the reduction in classroom time.

The aim of the course, the skill focus and topics covered remained the same as in Phase 2. 


\subsubsection{Phase 3 of course development - course outline}

\section{Class 1}

Introduction to the course, general instructions, agreeing on deadlines and other organizational issues. Students receive handouts, which are a combination of different materials pertaining to rules and tips for making a successful conference presentation (Task 1). All of the tasks are discussed with students and clarifications are made where necessary.

\section{Task 1}

Task 1 is completed online. Having been provided with several different papers/presentations, in the form of handouts, which contain tips for composing a successful oral presentation (Class1), the students are required to study the material, make their own list of most important steps/tips for writing and designing a conference presentation, and submit it online to the teacher by a set deadline. Students are provided with feedback on their lists via e-mail, and are given time to amend them, if necessary. After the lists are approved, the students are expected to follow their own list of rules when working on their presentation.

\section{Task 2}

Students receive handouts on conference presentation delivery via e-mail. This is a self-study unit that introduces students to useful phrases and provides tips on some important features such as: speed delivery, voice volume, use of emphasis, eye contact, body language, visual aids, etc. Students are required to complete the task incorporated in this paper and send it to the teacher by the set deadline. They are given feedback.

Regrettably, group work has been phased out of the first two tasks, in order to meet student needs for greater course flexibility. However, constant individual online communication with students is maintained.

\section{Task 3}

Students are provided with a list of presentation topics (taken from the curriculum), via e-mail. Each student chooses a different topic, and they are then individually given further instructions as to what exactly they are expected to cover. Students work on their power-point presentations and submit them by a set deadline. They are provided with feedback and they amend their presentations accordingly. Once the final versions of their presentations have been approved, they move on to the next task. Constant individual online communication with students is maintained throughout the process. 


\section{Task 4}

Students are provided with various materials on making a successful poster presentation (poster presentation dos and don'ts), via e-mail. By a set deadline they make their own lists of most important tips and rules on designing a conference poster and send them to the teacher, via e-mail. They receive feedback and amend their lists, if necessary.

\section{Task 5}

Students receive handouts, via e-mail: Data Presentation I and II (two self-study units that help students interpret tables, line graphs, pie charts, bar charts, describe trends and compare variables).

Students are expected to complete the tasks incorporated in the provided units and submit them, via e-mail, by the set deadline. They are given feedback. This unit provides them with valuable information and tips on using different forms of charts, tables and graphs, which are an integral part of conference posters, but also conference Power Point presentations.

\section{Task 6}

Task 6 is performed as a pair effort combining online communication (students with one another and with the teacher) and student pair work outside of class, when they meet to discuss and work on their joint assignment.

Students are given topics for their poster presentation in pairs. The so-called topics are, in fact, different research papers that they are supposed to read and then present in the form of a poster, following the rules of conference poster presentation. The students submit completed posters by a set deadline. They receive feedback and finalize their posters, after which the final versions of the posters are approved for printing and presenting. Communication with the teacher is maintained throughout the process and students are encouraged to ask questions whenever they need to, via e-mail.

\section{Class 2}

Class 2 is the second and final time when the students and the teacher meet as a group in a classroom setting. Students present their posters, in pairs, or their individual presentations, (as per their own choice). Each student is required to present, either the poster with their partner, or their own presentation. The rest of the students are required to comment on presentations/posters, providing useful feedback.

There is no formal exam. When students complete all the tasks, they are considered to have passed the exam.

Students have expressed a positive attitude towards this format of the course. They feel that the content and the way the tasks are designed and broken into smaller portions effectively meet their needs. At the same time, they appreciate the opportunity to work on their tasks at their own pace (within the set deadlines). 


\section{Conclusion: practical course implications}

The interactive elective courses English Language 3, 4, and 5 go beyond language teaching and learning and provide medical students with a set of valuable practical and academic skills necessary in their profession, which makes these courses interdisciplinary in nature and relevant to the needs of the students.

English Language 4 focuses on practical written and oral English skills necessary for participating in medical conferences, symposia, and other events where students of medicine and doctors present their findings and practical experience.

The course is highly appreciated by students, as repeatedly expressed by many of the groups and individual students.

\section{Further plans for course development}

In moving forward, the course needs to be set up on an online platform (e.g. Moodle) in order to maintain the element of peer review, which has, somewhat, been minimized with its transition from a blended to a predominantly online course. Enabling all content to be visible online to the entire group would stimulate peer debate and information exchange, which was formerly performed in class.

Additionally, such a platform would promote accessibility of material and facilitate a more active exchange with the teacher, including a more effective course evaluation by the students, which is a valuable resource for further course development. To this end, a structured evaluation form would need to be designed, as assessment of the course by students thus far has mainly been informal (comments in class and e-mails sent to the teacher). While informal input is valuable, and needs to be maintained, a formal standardized evaluation form would enable a more structured and scientific approach to course assessment, as it would provide objectively collected and analyzed information necessary for further course adjustment and development.

Finally, it is the opinion of the authors of this paper that a revision of the topics included in the course curriculum is long overdue. It is necessary to broaden the selection of topics offered and possibly make it an open ended one, where the students themselves would be able to suggest topics that may not have been included in the list. Namely, it has been noted throughout the course that, when students present on a topic close to their heart and very high on their list of medical fields of interest, they tend to be more motivated in executing their assignments. As the students taking this course are in year four of their medical training, it has also been noted, through class discussions, that most of them have already identified their specific areas of interest and appreciate opportunities to explore them. 


\section{References}

Barson, J. (1999). Dealing with Double Evolution: Action-based Learning Approaches and Instrumental Technology. In: R. Debski and M. Levy (eds.), World CALL Global perspectives on computer-assisted language learning, Lisse: Swets and Zeitlinger Publishers, 11-31.

Beaudoin, M. F. (2002). Learning or lurking? Tracking the invisible online student. Internet and Higher Education, 5(2), 147-155.

Chapelle, C. A. (2001). Computer applications in second language acquisition. Cambridge: Cambridge University Press.

Daud, N. M. and Zubairi, A. M. (2006). Online and Offline Writing Course. In: M. K. Kabilan et al. (eds.), Online Teaching and Learning in ELT, Pulau Pinang, Malaysia: Penerbit University Sains Malaysia, 7-20.

Dziombak, C. (1990). Searching for Collaboration in the ESL Computer Lab and the ESL Classroom. Unpublished $\mathrm{PhD}$ dissertation. Columbia University Teachers College.

Fotos, S. and C. M. Browne (2004). The Development of CALL and Current Options. In: S. Fotos and S. M. Browne (eds.), New Perspectives on CALL for Second Language Classroom, London: Lawrence Erlbaum Associates, 3-14.

Jović, M. and V. Stevanović (2015). Primena bloga u nastavi engleskog jezika. In: Savremena proučavanja jezika i književnosti, Zbornik radova sa VI naučnog skupa mladih filologa Srbije održanog 22. marta 2014. na Filološko-umetničkom fakultetu u Kragujevcu, Kragujevac: Filološko-umetnički fakultet, 371-381.

Kelm, O. (1992). The Use of Synchronous Computer Networks in Second Language Instructions: A Preliminary Report. Foreign Language Annals, 25(5), 441-454.

Kern, R. (1995). Restructuring Classroom Interaction with Networked Computers. Effects on Quantity and Quality of Language Production. Modern Language Journal, 79(4), 457-476.

Lungu, I. (2013). The Increasing Need for Blended-learning Models in Courses of English for Specific Courses in Romanian Universities. Procedia - Social and Behavioral Sciences, 76, 470-475.

Mijomanović, S., D. Sinadinović and S. Mićić Kandijaš (2018). Students' Reflections on an Online Elective Medical English Course. Primenjena lingvistika, 19, 4152.

Mićić, S. (2009). Izborna nastava engleskog jezika za student medicine. In: J. Vučo et al. (eds.), Jezik struke: Teorija i praksa. Zbornik radova, Beograd: Univerzitet u Beogradu, 483-488. 
Osguthorpe, R. T. and C. R. Graham (2003). Blended Learning Environments, Definitions and Directions. The Quarterly Review of Distance Education, 4(3), 227-233.

Sotillo, S. M. (2000). Discourse Functions and Syntactic Complexity in Synchronous and Asynchronous Communication. Language Learning and Technology, 4(1), $82-119$.

Sullivan, N. and E. Pratt (1996). A Comparative Study of Two ESL Writing Environments. A Computer-Assisted Classroom and a Traditional Oral Classroom. SYSTEM, 24(4), 491-501.

Thirunarayanan, M. O. and A. Perez-Prado (2001). Comparing Web-based and Classroom-based Learning. A Quantitative Study. Journal of Research on Computing in Education, 34(2), 131-137.

Veselá, K. (2012). Teaching English in new environments: CA-CLIL. Nitra: ASPA.

Young, J. R. (2002). 'Hybrid' Teaching Seeks to End the Divide Between Traditional and Online Instruction. Chronicle of Higher Education, 48(28), 33-34.

Yu-Chih, D. S. and L. Cifuentes (2001). One Tale of Why and How to Teach Online Internationally. Tech Trends, 45(6), 8-17. 